\title{
The relationship of motor skills with performance: Meta-analysis study
}

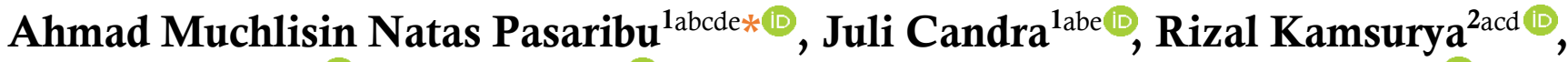 \\ Zainur $^{3}$ ac ${ }^{\mathbb{1}}$, Nurkadri $^{4}$ abc ${ }^{\mathbb{1}}$, Anak Agung Ngurah Putra Laksana ${ }^{5}$ acd \\ Universitas Bhayangkara Jakarta Raya, Indonesia ${ }^{1}$ \\ STKIP Media Nusantara Citra, Indonesia ${ }^{2}$ \\ Universitas Islam Riau, Indonesia ${ }^{3}$ \\ Universitas Negeri Medan, Indonesia ${ }^{4}$ \\ Universitas PGRI Mahadewa, Indonesia ${ }^{5}$
}

Received: 05 April 2021; Accepted 11 July 2021; Published 03 September 2021

Ed 2021; 6(3): 315-324

\begin{abstract}
This study aims to test the effect size of motor skills on the performance of a person in the field of sports. The type of research used is meta-analysis Studyes. The data sources in this study are google scholar, Jurnal SINTA, Scopus, and Eric. The livelihood of literature from various sources uses the keywords motor skills and performance. Data analysis is conducted through the stages of variable identification, identification of $r$ values, transforming the $\mathrm{r}$ value into the $\mathrm{z}$ distribution which is the size effect of each study, calculating variance, calculating the Error Standard of $z$, and calculating the summary effect. Summary effect calculation using Jeffreys's Amazing Statistics Program (JASP) software. The results showed that there was a significant positive correlation between motor skills and performace. The relationship of motor skills to performance falls into the moderate category with a random effect correlation value of 0.498 .
\end{abstract}

Keywords: Motor skills; performance; meta-analysis

https://doi.org/10.25299/sportarea.2021vol6(3).6647
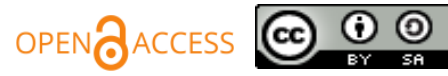

Copyright (C 2021 Ahmad Muchlisin Natas Pasaribu, Juli Candra, Rizal Kamsurya, Zainur, Nurkadri, Anak Agung Putra Laksana

Corresponding Author: Ahmad Muchlisin Natas Pasaribu, Department of Sport Coaching, Faculty of Education, Universitas Bhayangkara Jakarta Raya, DKI Jakarta, Indonesia

Email: ahmad.muchlisin@dsn.ubharajaya.ac.id

How to Cite: Pasaribu, A. M. N., Candra, J., Kamsurya, R., Zainur., Nurkadri., \& Laksana, A. A. P. (2021). The relationship of motor skills with performance: Meta-analysis study. Journal Sport Area, 6(3), $315-324$. https://doi.org/10.25299/sportarea.2021.vol6(3).6647

Authors' Contribution: a - Study Design; b - Data Collection; c - Statistical Analysis; d - Manuscript Preparation; e - Funds Collection

\section{INTRODUCTION}

Motor skill is one of the important factors in the development of individuals related to one's physical movements and activities in exercise (Sari \& Indahwati, 2016). Differences in the level of motor skills can impair a person's technical mastery speed and performance in sports activities (Doli et al., 2018). Hence, one's motor skills need to be trained and enhanced to help with basic technical mastery that positively impact performance in any sporting activity. Research on motor skills has been done extensively in the field of exercise. Such studyes indicate that motor skills have a positive effect on the accomplishments of both 
athletes and students in the various sports. But such results tend to vary, so a comprehensive analysis of overall motor skills in relation to the performance of a person requires.

Research performed by Mustafa and Sugiharto (2020) suggests that motor skills can produce dynamic results in motion activity for a student to perform a sports game. Further research done by Leonardo and Komaini (2021) concludes that there is a balance between physical activity and motor skills. It means that when the motor skills are good, then physical activity is also performed properly. Research done by Bahridah and Neviyarni (2021) states that to improve the quality of motion activity and improved performance, good motor skills are required.

One's motor development is an important aspect to consider. A person who has good motor skills is more conversational or otherwise active. It affects a person's confidence when he socializes or performs an activity. Rosenberg, Jacobi, and Bart (2017) reveals that a person with good motor skills will make activity more agile and prompt. Movements made are more coordinated and can increase confidence in activities. Further, good coordination of movement can help performance or performance become more maximum and premeditated. This will make him more adept at solving daily problems he faces (Mahmud, 2019). That statement is strengthened by Puspita et al., (2018) to achieve the maximum results in performing a movement or activity in sports requires good motor skills. Thus summarizing motor skill is a stage in development in the elements of maturity and control of one's movements. A person who has good motor skills can then control his exercise in carrying out a motion/activity to obtain a maximum result.

Basically, different motor skills in each child. One's motor skills could be seen from a basic motor. According to Zulrafli and Kamarudin (2021) motor skills were affected by the experience and activity of motor training. When a student had a disability in motion activities would hinder basic motion ability (Carisman et al., 2018). The same is said by Mahfud and Fahrizqi (2020) the impact of low motor skills could have on academic achievement.

Effort that could be made to improve student motor skills can be done by playing a sports game (Mahfud \& Fahrizqi, 2020). Similar presentations were also given Fajar (2017) by engaging in sports activities will enhance and enhance student motor skills. Rismayanthi (2013) it also explained that through sporting activities, stimulus to student motor skills would increase. From the foregoing findings, it might be concluded that efforts in developing a student's motor skills could be made by providing physical activity that could help the performance of the student. Based on the background of this problem the purpose of this study is to test an effect size from the motor skills to performance in sports which was done through the meta-analysis study.

\section{METHOD}

The type of research used was meta-analysis study. Meta-analysis was one type of analysis in statistics done by combining results from 2 or more similar Studyes for quantitative data combined (Anwar et al., 2005). The meta-analysis study was conducted in this study to test an effect size from the motor skills of a person's performance in sports. Steps to conducting meta-analysis Studyes (1) selecting and studying research topics, (2) collecting a number of results with appropriate headings, (3) counting effect size, (4) identifying heterogeneity effect size, (4) interpreting the research and drawing conclusions DE coster in (Waluyohadi, 2019).

The data sources in this study were derived from scientific literature sources of research articles published in national journals and international journals. Data acquisition was made online through Google scholar, a cystic national journal, scopus, and Eric library. The livelihood of articles involved visiting the website of each source - https://,google.com, httpsscholar://a.brin.go. Id, https://www.scopus.com, and https://eric.ed.gov, using key words "motor skills" and "motor ability," "sports performance," and "sport performance."

The study population was 278 articles obtained from various sources. Sampling samples were conducted using a certain constituent random sampling, which was a sample retrieval technique using specific criteria. The selection criteria for a sample selection using the inclusion and excretion criteria set in the study are (1) a Sinta, Scopus, and Eric article (2) discussing motoric and performance abilities in sports, (3) articles 
published in 2011-202, (4) articles using quantitative research design, particularly corelational, and (4) the article is not restricted to the author's origin. Selection of samples obtained 32 Studyes qualified for inclusion and exclusion to be analyzed, as shown in the following figure 1 .

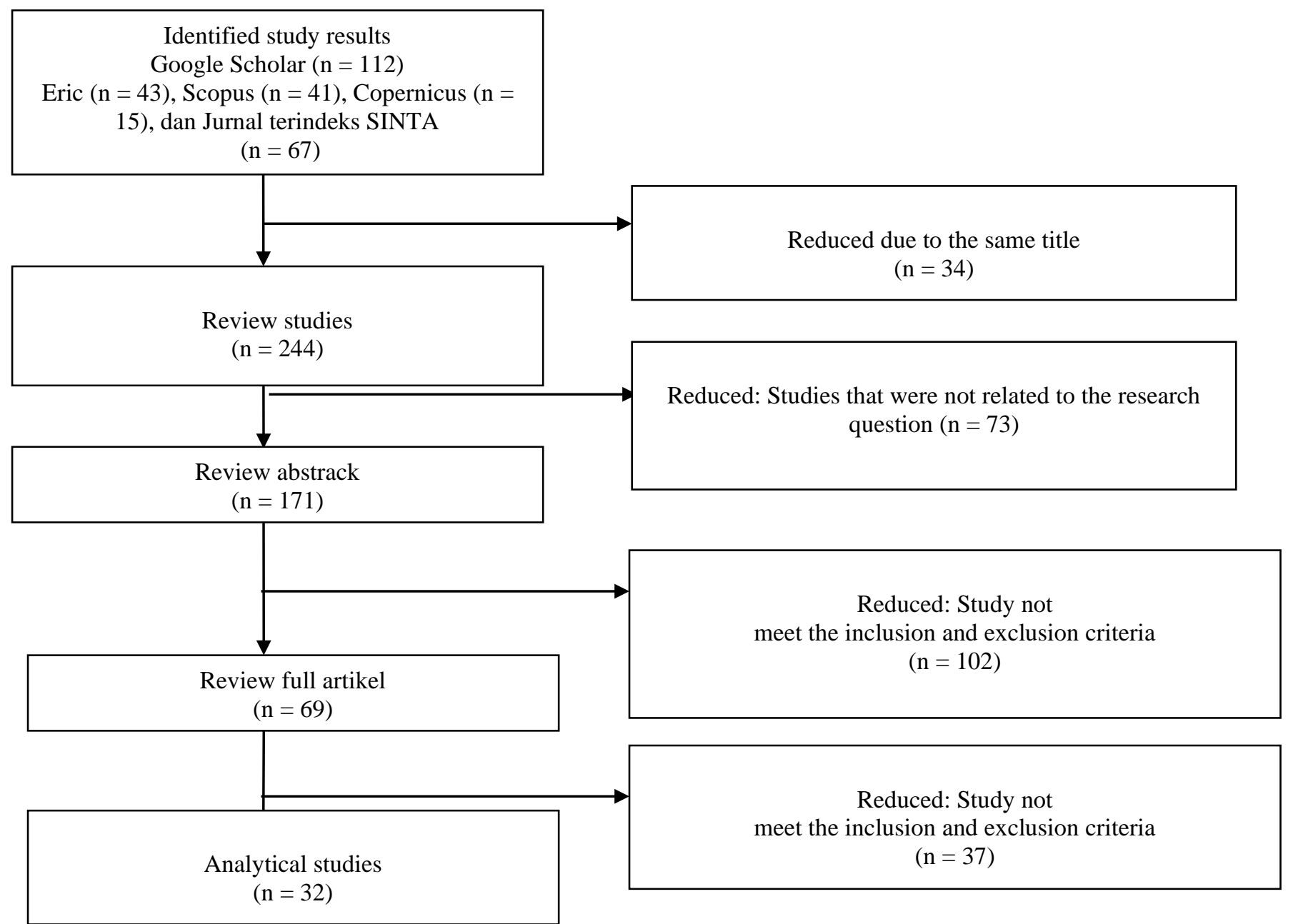

Figure 1. Diagram the Flow of Search Strategies to Identify the Study Who Qualified for Meta-Analysis

Data livelihood from multiple sources, and data analysis stages were done through (1) research variable identification. After being found, enter in the corresponding variable column, (2) value identification was on each of the articles analysed. If Studyes that were reported to contain only a fort, then are transformed into an area value, using equations:

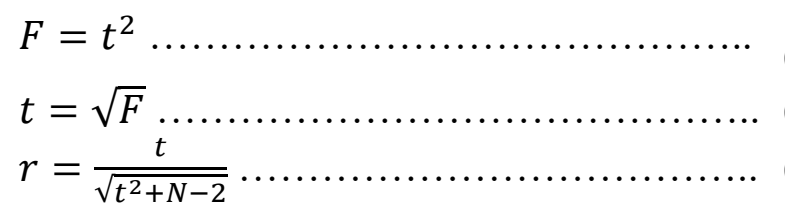

(3) transforming the value of were to the distribution of the $z$ which was a size effect from each study, then accounting for variance, (4) accounting for errors' standards from $z$, and (5) accounting for the summary effect of the entire study (Retnawati et al., 2018). Calculating summary derived involves using meta-analysis for Jeffreys' Amazing Statistics Program (JASP). 


\section{RESULTS AND DISCUSSION}

Meta-analysis study was conducted on 39 research Studyes obtained from Google Scholar, Eric, Scopus, and Pubmed. A total of 239 articles did not meet both the inclusion and the exclusion criteria for analysis of a total of 278 Studyes obtained regarding the relationships of motor skills with the performance. The study analysed was presented at the following table 1 .

Table 1. Eligible Studyes and Conducted Meta-Analysis

\begin{tabular}{|c|c|c|c|c|c|c|c|}
\hline No & Authors/Year & Name of Journal & $\begin{array}{c}\text { Indeks of } \\
\text { Jurnal }\end{array}$ & $\begin{array}{c}\text { Sample } \\
\text { Characteristics }\end{array}$ & $\mathbf{N}$ & $\begin{array}{c}\text { Measurement } \\
\text { Variable } \\
\end{array}$ & $\mathbf{R}$ \\
\hline 1 & Sulaeman, (2019) & $\begin{array}{c}\text { Exercise : Journal of } \\
\text { Physical Education } \\
\text { and Sport }\end{array}$ & Sinta 4 & College student & 20 & $\begin{array}{l}\text { Long Distance } \\
\text { Jump }\end{array}$ & 0.8940 \\
\hline 2 & $\begin{array}{c}\text { Ramadan \& } \\
\text { Ningrum, (2019) } \\
\text { Study } 1 \\
\end{array}$ & $\begin{array}{c}\text { JUARA : Jurnal } \\
\text { Olahraga }\end{array}$ & Sinta 3 & Junior High School & 21 & $\begin{array}{l}\text { Lay-up shoot } \\
\text { (Basket) }\end{array}$ & 0.5359 \\
\hline 3 & $\begin{array}{c}\text { Ramadan \& } \\
\text { Ningrum, (2019), } \\
\text { Study } 2 \\
\end{array}$ & $\begin{array}{c}\text { JUARA : Jurnal } \\
\text { Olahraga }\end{array}$ & Sinta 3 & Junior High School & 21 & BasketBall & 0.5023 \\
\hline 4 & $\begin{array}{l}\text { Nikšić et al., } \\
\text { (2019) }\end{array}$ & $\begin{array}{c}\text { Pedagogics, } \\
\text { Psychology, Medical- } \\
\text { Biological Problems of } \\
\text { Physical Training and } \\
\text { Sports } \\
\end{array}$ & $\begin{array}{c}\text { Eric \& } \\
\text { PubMed }\end{array}$ & Elementary School & 53 & $\begin{array}{l}\text { Long Distance } \\
\text { Jump }\end{array}$ & -0.0434 \\
\hline 5 & $\begin{array}{l}\text { Pešić et al., } \\
\text { (2015) }\end{array}$ & $\begin{array}{l}\text { Facta Universitatis: } \\
\text { Series Physical } \\
\text { Education \& Sport }\end{array}$ & $\begin{array}{l}\text { Scopus } \\
\text { (Q3) }\end{array}$ & Junior High School & 15 & Swimming & 0.7228 \\
\hline 6 & Saputra, (2018) & $\begin{array}{l}\text { Journal of Physical } \\
\text { Education and Sports }\end{array}$ & Sinta 4 & Elementary School & 44 & Pencak Silat & 0.7947 \\
\hline 7 & $\begin{array}{c}\text { Naldi \& Irawan, } \\
\text { (2020) }\end{array}$ & $\begin{array}{c}\text { Jurnal Performa } \\
\text { Olahraga }\end{array}$ & Sinta 5 & Elementary School & 25 & Foot Ball & 0.4670 \\
\hline 8 & $\begin{array}{c}\text { Muharram, } \\
\text { (2015) }\end{array}$ & Jurnal Sportif & Sinta 2 & Elementary School & 40 & Run 100 meter & 0.3855 \\
\hline 9 & $\begin{array}{c}\text { Pahliwandari et } \\
\text { al., (2018) }\end{array}$ & $\begin{array}{c}\text { Jurnal Pendidikan } \\
\text { Olahraga }\end{array}$ & Sinta 4 & College student & 35 & Volly Ball & 0.7660 \\
\hline 10 & Sepriadi, (2017) & Jurnal Keolahragaan & Sinta 2 & Elementary School & 34 & Physical Fitness & 0.8020 \\
\hline 11 & Nuryadi, (2018) & $\begin{array}{c}\text { Jurnal Fakultas } \\
\text { Keguruan Dan Ilmu } \\
\text { Pendidikan }\end{array}$ & Copernicus & Elementary School & 40 & BasketBall & 0.3819 \\
\hline 12 & Solissa, (2014) & $\begin{array}{c}\text { Journal of Physical } \\
\text { Education Health and } \\
\text { Sport }\end{array}$ & Sinta 3 & College student & 90 & Taekwondo & 0.5165 \\
\hline 13 & $\begin{array}{c}\text { Dewi \& } \\
\text { Sitompul, (2016) }\end{array}$ & $\begin{array}{l}\text { Jurnal Teknologi } \\
\text { Pendidikan (JTP) }\end{array}$ & Sinta 4 & Junior High School & 77 & Foot Ball & 0.2270 \\
\hline 14 & Doli et al., (2018) & $\begin{array}{c}\text { Jurnal Pedagogik } \\
\text { Olahraga } \\
\end{array}$ & Copernicus & Senior High School & 40 & Foot Ball & 0.7433 \\
\hline 15 & $\begin{array}{l}\text { Setiawan et al., } \\
\qquad(2020)\end{array}$ & $\begin{array}{l}\text { Journal of Teaching } \\
\text { Physical Education in } \\
\text { Elementary School }\end{array}$ & Sinta 4 & Elementary School & 24 & Gymnastics & 0.7807 \\
\hline 16 & $\begin{array}{c}\text { Semarayasa, } \\
(2016)\end{array}$ & $\begin{array}{l}\text { Jurnal Pendidikan } \\
\text { Jasmani Indonesia }\end{array}$ & Sinta 3 & College student & 40 & Sepak Takraw & 0.6076 \\
\hline 17 & $\begin{array}{c}\text { Fong et al., } \\
(2011), \text { Study } 2\end{array}$ & \multirow{3}{*}{$\begin{array}{l}\text { Research in } \\
\text { Developmental } \\
\text { Disabilities }\end{array}$} & $\begin{array}{c}\text { Scopus } \\
\text { (Q2) }\end{array}$ & Elementary School & 83 & Diversity & 0.2640 \\
\hline 18 & $\begin{array}{c}\text { Fong et al., } \\
\text { (2011), Study } 3\end{array}$ & & $\begin{array}{c}\text { Scopus } \\
(\mathrm{Q} 2)\end{array}$ & Elementary School & 83 & Recreation & 0.2490 \\
\hline 19 & $\begin{array}{c}\text { Fong et al., } \\
(2011), \text { Study } 4\end{array}$ & & $\begin{array}{c}\text { Scopus } \\
\text { (Q2) }\end{array}$ & Elementary School & 83 & Skill & 0.2350 \\
\hline 20 & $\begin{array}{l}\text { Boichuk et al., } \\
\text { (2017) }\end{array}$ & $\begin{array}{l}\text { Journal of Physical } \\
\text { Education and Sport }\end{array}$ & $\begin{array}{c}\text { Scopus } \\
\text { (Q3) }\end{array}$ & Senior High School & 20 & BasketBall & 0.4530 \\
\hline
\end{tabular}




\begin{tabular}{|c|c|c|c|c|c|c|c|}
\hline No & Authors/Year & $\begin{array}{l}\text { Name of } \\
\text { Journal }\end{array}$ & $\begin{array}{c}\text { Indeks of } \\
\text { Jurnal }\end{array}$ & $\begin{array}{c}\text { Sample } \\
\text { Characteristics }\end{array}$ & $\mathbf{N}$ & $\begin{array}{c}\text { Measurement } \\
\text { Variable }\end{array}$ & $\mathbf{R}$ \\
\hline 21 & $\begin{array}{l}\text { Vukasevic et al., } \\
\text { (2020), Study } 1\end{array}$ & \multirow{11}{*}{ Sport Mont } & Scopus (Q2) & College student & 48 & BasketBall & 0.0839 \\
\hline 22 & $\begin{array}{l}\text { Vukasevic et al., } \\
(2020), \text { Study } 2\end{array}$ & & Scopus (Q2) & College student & 48 & BasketBall & 0.2991 \\
\hline 23 & $\begin{array}{l}\text { Vukasevic et al., } \\
(2020), \text { Study } 3\end{array}$ & & Scopus (Q2) & College student & 48 & BasketBall & -0.207 \\
\hline 24 & $\begin{array}{l}\text { Vukasevic et al., } \\
\text { (2020), Study } 4\end{array}$ & & Scopus (Q2) & College student & 48 & BasketBall & -0.112 \\
\hline 25 & $\begin{array}{l}\text { Vukasevic et al., } \\
\text { (2020), Study } 5\end{array}$ & & Scopus (Q2) & College student & 48 & BasketBall & -0.047 \\
\hline 26 & $\begin{array}{l}\text { Vukasevic et al., } \\
\text { (2020), Study } 6\end{array}$ & & Scopus (Q2) & College student & 48 & BasketBall & -0.108 \\
\hline 27 & $\begin{array}{l}\text { Vukasevic et al., } \\
(2020), \text { Study } 7\end{array}$ & & Scopus (Q2) & College student & 48 & BasketBall & 0.079 \\
\hline 28 & $\begin{array}{l}\text { Vukasevic et al., } \\
(2020), \text { Study } 8\end{array}$ & & Scopus (Q2) & College student & 48 & BasketBall & 0.022 \\
\hline 29 & $\begin{array}{l}\text { Vukasevic et al., } \\
\text { (2020), Study } 9\end{array}$ & & Scopus (Q2) & College student & 48 & BasketBall & -0.108 \\
\hline 30 & $\begin{array}{c}\text { Khodaverdi \& Bahram, } \\
\text { (2015), Study } 1\end{array}$ & & Scopus (Q3) & Junior High School & 24 & Physical Activity & 0.4470 \\
\hline 31 & $\begin{array}{l}\text { Khodaverdi \& Bahram, } \\
\text { (2015), Study } 2\end{array}$ & & Scopus (Q3) & Junior High School & 24 & Physical Activity & 0.1350 \\
\hline
\end{tabular}

\section{Heterogeneity Test Results}

The heterogeneity test was conducted to determine the heterogeneity level of the analyzed Studyes. The test results are in table 2 below.

Tabel 2. Fixed and Random Effects

\begin{tabular}{lccc} 
& Q & df & p \\
& Q & $<.001$ \\
Omnibus test of Model Coefficients & 41.286 & 1 & $<.001$ \\
Test of Residual Heterogeneity & 366.978 & 38 & \\
\hline
\end{tabular}

Table 2 showed that the 32-effect size from the analyzed study was heterogeneous $(q=187,030, p-001)$, where the p-value 0.05 . Thus, the random effect model was more appropriate to estimate the mean effect size from the 32 analyzed Studyes. The above indicates that there was a potential for investigating moderator variables that affect the relationship between motor skills and performance.

\section{Result Summary Effect/Mean Effect Size}

The summary effect test aimed to calculate the level of correlation between motor skills and performance variables based on the random effect correlation value. The test results were in Table 3 below.

Tabel 3. Coefficients

\begin{tabular}{ccccccc}
\hline & \multicolumn{1}{c}{ 95\% Confidence Interval } & & \\
\hline & Estimate & Standard Error & $\mathbf{z}$ & p & Lower & Upper \\
\hline Intercept & 0.409 & 0.074 & 5.501 & $<0.001$ & 0.263 & 0.555 \\
\hline
\end{tabular}

Note. Wald test.

Table 3 showed that the results of the analysis using the random effects model showed that there was a significant positive correlation between motor skills and performance $(\mathrm{z}=5.501, \mathrm{p}<0.001 .95 \%$ CI,[0263;0.555]). The relationship between motor skills and performance were in the moderate category with the correlation value of Random Effect $\left(r_{-}\right.$RE) $=0.409$ (Cohen, 1988). Furthermore, the distribution of effect sizes from each study was found in the following forest plot. 


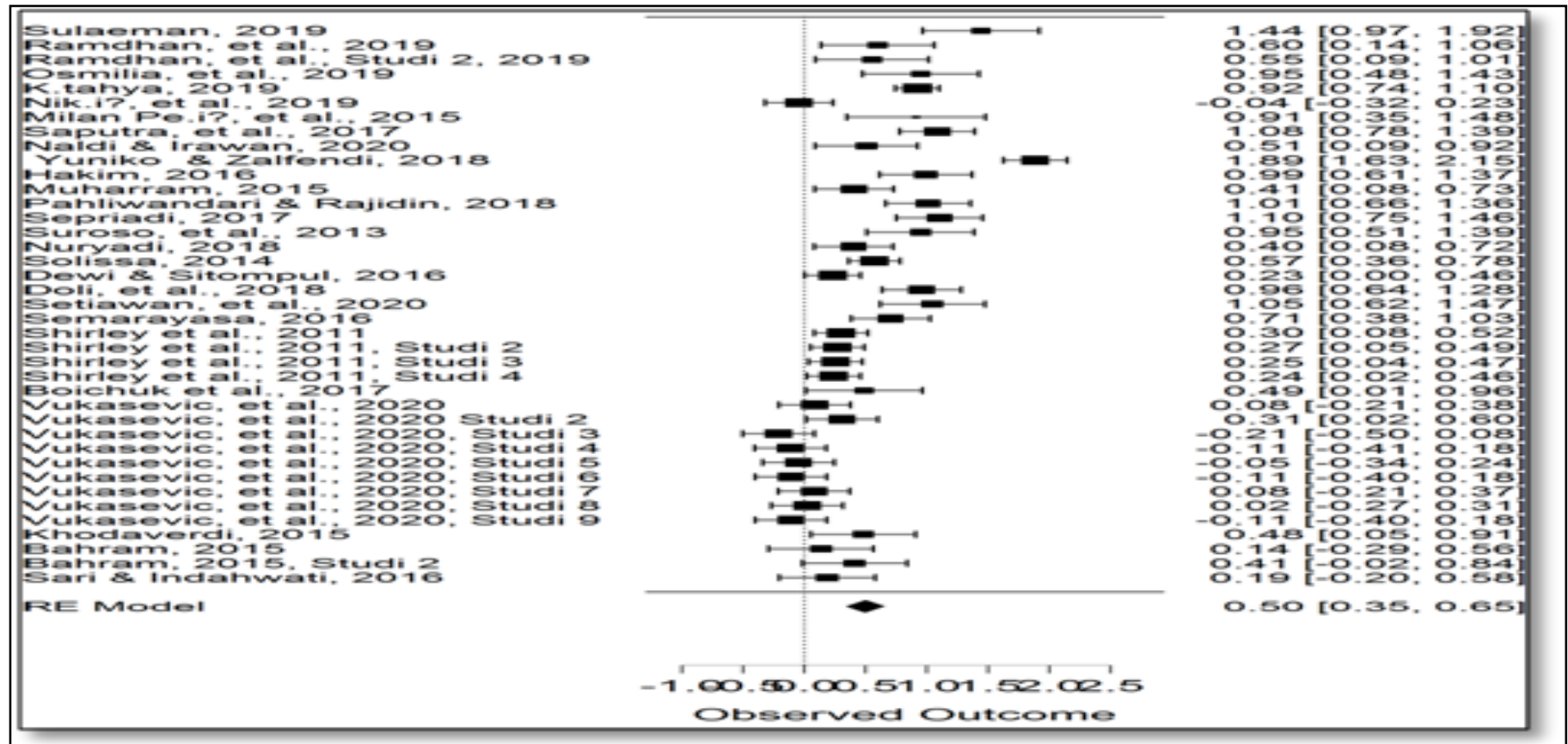

Figure 2. Forest Plots Deployment Effect Size

Based on Figure 1. the forest plot, The data could be seen that the effect size of the analyzed Studyes varies between -0.21 to 1.44 . The figure above also showed that the reported Studyes had different results, thus impacting the spread of effect size across each study.

\section{Publication Bias Analysis}

Publication bias analysis was conducted to determine the existence of bias from each study analyzed. The results of the publication bias analysis in the meta-analysis Studyes carried out are shown in Figure 2 below.

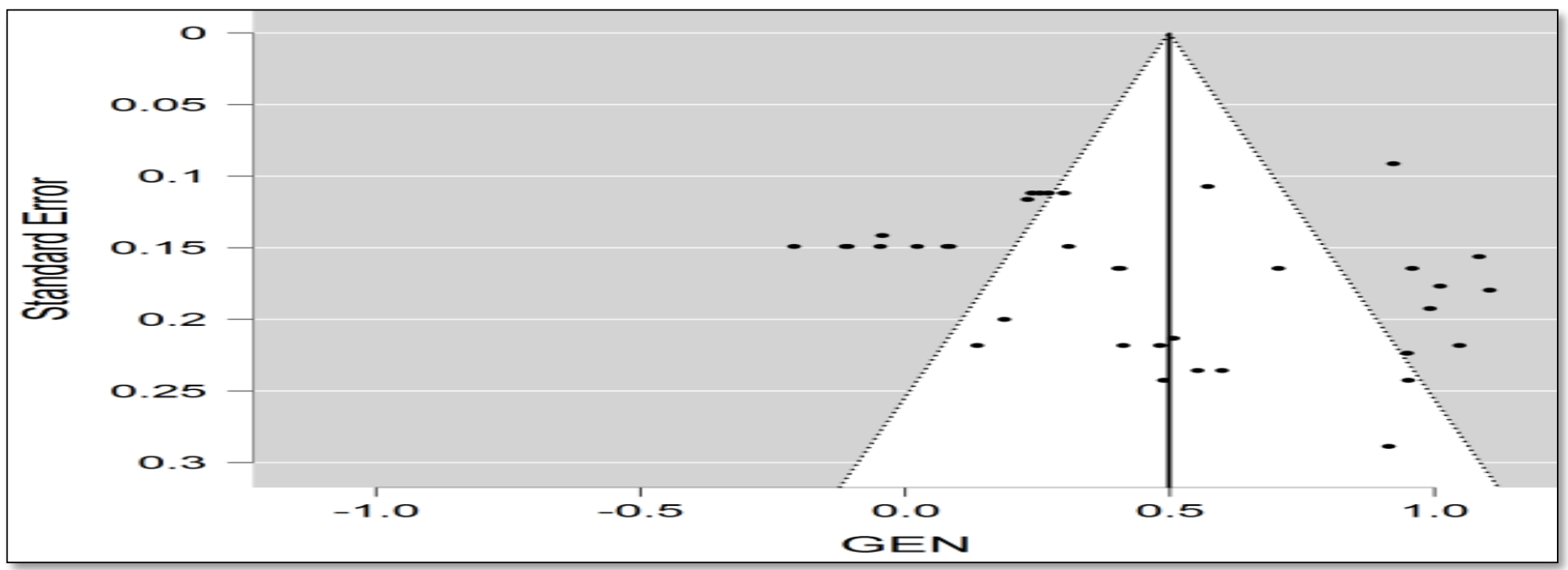

Figure 3. Fubbel Plots Analysis Results

Figure 2. The funnel plot above was difficult to show whether the plot was symmetrical or not, so an Egger test was needed to test the symmetry of the plot, so that accurate conclusions could be obtained regarding whether there is publication bias based on the results of the analysis carried out. The results of the Egger's test analysis are shown in Table 4 below. 
Table 4. Regression Test for Funnel Plot Asymmetry ("Egger's test")

\begin{tabular}{ccc}
\hline & $\mathbf{Z}$ & $\mathbf{P}$ \\
\hline Sei & 1.889 & 0.059 \\
\hline
\end{tabular}

Based on Table 4 above, the results of the Egger test appear that the p-value $<0.05$ "or "0.0003 $<0.05$. In this way, the data could be concluded that there's no publication bias issue within the meta-analysis considers conducted. To get a high level of precision, distribution inclination was also carried out utilizing Record Drawer Examination or Fail-safe N, which appears in Table 5 underneath.

Table 5. File Drawer Analysis

\begin{tabular}{|c|c|c|c|}
\hline & Fail-safe $\mathbf{N}$ & Target Significance & Observed Significance \\
\hline Rosenthal & 4.954 .000 & 0.050 & $<.001$ \\
\hline
\end{tabular}

Motor skills were basically the ability underlying a common and fundamental motion that contributes to effective movements in sports (Zulkifli et al., 2018). Motor skills played an integral part in a person's performance in sports activities, as one's physical movements or activities were influenced by his or her motor affinity (Ramadan \& Ningrum, 2019). In addition, the one's own motor skill factor could be one's mastery contributing factor in the basic engineering mastery of the sport (Zulkifli et al., 2018). Analysis showed that there were a significant and positive relationship between the performance of the motor skills, in which the relationship between the two variables falls under the moderate category with the value of the are _re $=0.409$ that indicates that the better the motor skills, the more physical activity done will be maximum (Sulaeman, 2019). This study reinforced previously made Studyes that motor skills correlate positively with one's performance in sports (Naldi \& Irawan, 2020; Ramadan \& Ningrum, 2019; Semarayasa, 2016; Solissa, 2014). Thus one's motor skills needed attention and thought for improvement because they could affect one's sporting activities (Piek et al., 2006).

The find described a statistical similarity of motor skills to the performance of $14.55 \%$ with a heterogeneous study (I: $2=85.45 \%$ ). The findings indicate that the performance of a person in the field of exercise did not depend entirely on his or her own motor skills. A person's performance on a sport's maximum or lack thereof was determined more than the natural engineering mastery of the sport (Wu et al., 2007). Good basic technical mastery made it easier for a person to make the move in a sport, since the action he does is more relaxed, effective, and efficient (Malik \& Rubiana, 2019). In addition to this kind of regular exercise and exercise schedule needed to be considered to increase one's performance. Although this aspect was not specifically analyzed, the results of the Aprianova and Hariadi (2016) show that an appropriate, regular type of exercise on a sport could make a person's movement better, and enhanced a person's basic technical ability.

While the image of analysis on fubbel plots did not show specifically whether or not publication bias based on degenerated Studyes, egger's test and fail-safe analysis indicated lack of publication bias. This suggests that a meta-analysis study of motor skills in relation to the performance of a person could be accepted as an accurate and consistent analysis.

\section{CONCLUSION}

Research suggests that there was a significant positive correlation between motor skills and performance. The performance's motor skills included a moderate category with random effect ( $\mathrm{r}$ characteristics _re) value $=0.409$. The results of this study were merely a summary effect of the impact motor skills can have on performance in sports. Advanced research that could be done that test the influence of moderate variables on the performance of sports. 


\section{ACKNOWLEDGEMENT}

This research can be carried out thanks to the support of FKIP Universitas Bhayangkara Jakarta Raya, STKIP Media Citra Nusantra, Universitas Negeri Medan, Universitas Riau, and Universitas PGRI Mahadewa. The author also thanks for the trust of the entire team who helped in completing this research.

\section{CONFLICT OF INTEREST}

The results of this study do not have conflict of interest with any parties, either from the funding party or the research location, so that the results of this study can be published.

\section{REFERENCES}

Anwar, R. (2005). Meta Analisis. Bandung: Unpad Press.

Aprianova, F., \& Hariadi, I. (2016). Metode drill untuk meningkatkan teknik dasar menggiring bola (dribbling) dalam permainan sepakbola pada siswa sekolah sepakbola putera Zodiac Kabupaten Bojonegoro usia 13-15 tahun. Jurnal Kepelatihan Olahraga, 1(1), 63-74.

Bahridah, P., \& Neviyarni. (2021). Faktor-faktor yang mempengaruhi keterampilan motorik dalam pembelajaran. Jurnal Pendidikan Tematik, 2(1), 13-19.

Boichuk, R., Iermakov, S., Nosko, M., Kovtsun, V., \& Nosko, Y. (2017). Influence of motor coordination indicators on efficiency of game activity of volleyball players at the stage of specialized basic training. Journal of Physical Education and Sport, 17(4), 2632-2637. https://doi.org/10.7752/jpes.2017.04301

Chrisman, J. J., Chua, J. H., Le Breton-Miller, I., Miller, D., \& Steier, L. P. (2018). Governance mechanisms and family firms. Entrepreneurship: Theory and Practice, 42(2), 171-186. https://doi.org/10.1177/1042258717748650

Dewi, C. C., \& Sitompul, H. (2016). Pengaruh Pemberian umpan balik dan kemampuan motorik terhadap hasil belajar shooting siswa SMP Negeri di Kecamatan Langsa Kota. Jurnal Teknologi Pendidikan (JTP), 9(1), 14-25. https://doi.org/10.24114/jtp.v9i1.4888

Doli, M. F., Akhmad, I., \& Sunarno, A. (2018). Pengaruh gaya mengajar dan kemampuan motorik terhadap hasil belajar dribbling sepakbola pada siswa kelas XI MAN 2 Model Medan. Jurnal Pedagogik Olahraga, 4(2), 16-31.

Fajar, M. (2017). Peranan intelegensi terhadap perkembangan keterampilan fisik motorik peserta didik dalam pendidikan jasmani. Multilateral: Jurnal Pendidikan Jasmani dan Olahraga, 16(1), 58-66. https://doi.org/10.20527/multilateral.v16i1.3664

Fong, S. S. M., Lee, V. Y. L., Chan, N. N. C., Chan, R. S. H., Chak, W., \& Pang, M. Y. C. (2011). Research in developmental disabilities motor ability and weight status are determinants of out-of-school activity participation for children with developmental coordination disorder. Research in Developmental Disabilities, 32(6), 2614-2623. https://doi.org/10.1016/j.ridd.2011.06.013

Khodaverdi, F., \& Bahram, A. (2015). Relationship between motor skill competence and physical activity in girls. Annals of Applied Sport Science, 3(2), 43-50. https://doi.org/10.18869/acadpub.aassjournal.3.2.43

Leonardo, A., \& Komaini, A. (2021). Hubungan aktivitas fisik terhadap keterampilan motorik. Jurnal Stamina, 4(3), 135-144.

Mahfud, I., \& Fahrizqi, E. B. (2020). Pengembangan model latihan keterampilan motorik melalui olahraga tradisional untuk siswa sekolah dasar. Sport Science and Education Journal, 1(1), 31-37. https://doi.org/10.33365/.v1i1.622

Mahmud, B. (2019). Urgensi stimulasi kemampuan motorik kasar pada anak usia dini. DIDAKTIKA : Jurnal Kependidikan, 12(1), 76-87. https://doi.org/10.30863/didaktika.v12i1.177 
Malik, A. A., \& Rubiana, I. (2019). Kemampuan teknik dasar bola basket: study deskriptif pada mahasiswa. Journal of SPORT (Sport, Physical Education, Organization, Recreation, and Training), 3(2), 79-84. https://doi.org/10.37058/sport.v3i2.1238

Muharram, N. A. (2015). Pengaruh Pembelajaran dan kemampuan gerak dasar terhadap peningkatan kemampuan sprint 100 Meter. Jurnal Sportif, 1(1), 22-31. https://doi.org/10.29407/js_unpgri.v1i1.572

Mustafa, P. S., \& Sugiharto, S. (2020). Keterampilan motorik pada pendidikan jasmani meningkatkan pembelajaran gerak seumur hidup. Sporta Saintika, 5(2), 199-218. https://doi.org/10.24036/sporta.v5i2.133

Naldi, I. Y., \& Irawan, R. (2020). Kontribusi kemampuan motorik terhadap kemampuan teknik dasar pada atlet SSB (Sekolah Sepakbola) Balai Baru Kota Padang. Performa Olahraga, 5(1), 6-11. https://doi.org/10.24036/jpo133019

Nikšić, E., Beganović, E., Rašidagić, F., Mirvić, E., \& Joksimović, M. (2019). The effects of physical education on changes of basic motor skills of female students in the fifth grade of elementary school. Pedagogics, Psychology, Medical-Biological Problems of Physical Training and Sports, 23(6), 296305. https://doi.org/10.15561/18189172.2019.0604

Nuryadi, A. (2018). Pengaruh model pembelajaran dan tingkat kemampuan perseptual motorik siswa terhadap hasil belajar keterampilan. Buana Pendidikan: Jurnal Fakultas Keguruan dan Ilmu Pendidikan, 11(20), 10-20. https://doi.org/10.36456/bp.vol11.no20.a1353

Pahliwandari, R., Asmutiar, \& Rajidin. (2018). Pengaruh Keterampilan Motorik Terhadap Hasil Belajar Passing Bawah Bolavoli Penjaskesrek IKIP PGRI Pontianak. Jurnal Pendidikan Olahraga, 7(1), 7582.

Pešić, M., Okičić, T., Madić, D., Dopsaj, M., Djurovic, M., \& Djordjevic, S. (2015). the Effects of Additional Strength Training on Specific Motor Abilities in Young Swimmers. /Uticaj Dodatnog Treninga Snage Na Specifične Motoričke Sposobnosti Mladih Plivača. Facta Universitatis: Series Physical Education \& Sport, 13(2), 291-301.

Piek, J. P., Baynam, G. B., \& Barrett, N. C. (2006). The relationship between fine and gross motor ability, self-perceptions and self-worth in children and adolescents. 25, 65-75. https://doi.org/10.1016/j.humov.2005.10.011

Puspita, D., Calista, W., \& Suyadi, S. (2018). Perkembangan Fisik-Motorik Siswa Usia Dasar: Masalah dan Perkembangannya. JIP: Jurnal Ilmiah PGMI, 4(2), 170-182. https://doi.org/10.19109/jip.v4i2.2780

Ramadan, G., \& Ningrum, D. A. (2019). Pengaruh Kemampuan Motorik, Imagery dan Motivasi Terhadap Hasil Belajar Lay-up Shoot. JUARA: Jurnal Olahraga, 4(1), 36. https://doi.org/10.33222/juara.v4i1.399

Retnawati, H., Apino, E., Kartianom, Djidu, H., \& Anazia, R. D. (2018). Pengantar Analisis Meta. Parama Publishing.

Rismayanthi, C. (2013). Mengembangkan Keterampilan Gerak Dasar Sebagai Stimulasi Motorik Bagi Anak Taman Kanak-Kanak Melalui Aktivitas Jasmani. Jurnal Pendidikan Jasmani Indonesia, 9(1), 64-72. https://doi.org/10.21831/jpji.v9i1.3065

c, L., Jacobi, S., \& c, O. (2017). Executive functions and motor ability contribute to children's participation in daily activities. Journal of Occupational Therapy, Schools, \& Early Intervention, 23(2), 1-12. https://doi.org/10.1080/19411243.2017.1312660

Saputra, V. D. (2018). The Influence of teaching style and motor ability level toward pencak silat learning results on the fifth grade students of SD Hj Isriati Baiturrahman 2 Semarang City. Journal of Physical Education and Sports, 7(2), 100-104. https://doi.org/10.15294 /jpes.v7i2.23609 
Sari, D. S., \& Indahwati, N. (2016). Hubungan kemampuan motorik dan motivasi belajar terhadap hasil belajar pendidikan jasmani, olahraga dan kesehatan (study pada siswa kelas IV dan V SDN Pandankrajan 2 Mojokerto). Jurnal Pendidikan Olahraga dan Kesehatan, 4(3), 556-563.

Semarayasa, I. K. (2016). Pengaruh Strategi Pembelajaran dan Tingkat Motor Ability Terhadap Keterampilan Servis Atas Sepak. Jurnal Pendidikan Jasmani Indonesia, 12(1), 34-41. https://doi.org/10.21831/jpji.v12i1.10214

Sepriadi, S. (2017). Kontribusi status gizi dan kemampuan motorik terhadap kesegaran jasmani siswa sekolah dasar. Jurnal Keolahragaan, 5(2), 194-206. https://doi.org/10.21831/jk.v5i2.15147

Setiawan, A., Yudiana, Y., Ugelta, S., Oktriani, S., Budi, D. R., \& Listiandi, A. D. (2020). Hasil belajar pendidikan jasmani dan olahraga siswa sekolah dasar: pengaruh keterampilan motorik (tinggi) dan model pembelajaran (kooperatif). TEGAR: Journal of Teaching Physical Education in Elementary School, 3(2), 59-65. https://doi.org/10.17509/tegar.v3i2.24513

Solissa, J. (2014). Pengaruh metode latihan dan kemampuan motorik terhadap daya ledak tendangan dollyo chagi taekwondo. Journal of Physical Education Health and Sport, 1(1), 41-47. https://doi.org/10.15294/jpehs.v1i1.3011

Sulaeman. (2019). Analisis motor ability terhadap kemampuan lompat jauh. Exercise: Journal of Physical Education and Sport, 1(2), 77-85.

Vukasevic, V., Mitrovic, M., \& Masanovic, B. (2020). A comparative study of motor ability between elite basketball players from different regions. Sport Mont, 18(1), 3-7. https://doi.org/10.26773/smj.200201

Waluyohadi, A. E. G. (2019). Meta-analysis Study of Achievement Motivation and Academic Achievement. Psikodimensia, 18(2), 101-108. https://doi.org/10.24167/psidim.v18i2.2023

Wu, T., Zang, Y., Wang, L., Long, X., Hallett, M., Chen, Y., Li, K., \& Chan, P. (2007). Aging influence on functional connectivity of the motor network in the resting state. Neuroscience Letters, 422(3), 164168. https://doi.org/10.1016/j.neulet.2007.06.011

Zulkifli, Z., Asmawi, M., \& Hanif, A. (2018). Effect of teaching styles and motor ability on results learning sepak takraw basic techniques. JIPES - Journal of Indonesian Physical Education and Sport, 4, 46-54. https://doi.org/10.21009/JIPES.042.07

Zulrafli, \& Kamarudin. (2021). The analysis of motor ability of physical education students. Journal Sport Area, 6(1), 1-9. https://doi.org/10.25299/sportarea.2021vol6(1).4097 